François Ir de Médicis, au Palazzo Vecchio de Florence. C'est " l'inversion zodiacale et l'harmonie des éléments » qui permet de comprendre l'union mise en place.

Ajoutons que l'ouvrage est magnifiquement illustré de soixante-dix-sept reproductions (toutes en couleur, du moins quand il ne s'agit pas de gravures) parfaitement situées qui permettent une lecture aisée, de grand profit et passionnante.

FRANÇOIS ROUDAUT

Université de Montpellier

\title{
Hill, Kat.
}

Baptism, Brotherhood, and Belief in Reformation Germany: Anabaptism and Lutheranism, 1525-1585.

Oxford: Oxford University Press, 2015. Pp. xii + $268+7$ ill. ISBN 978-0-19873354-6 (hardcover) US $\$ 105$.

This is an ambitious book that promises many new and exciting things to its readers, who should include scholars not only of Anabaptism but of the Reformation and of early modern religious history more generally. On one level it claims to redress a deficit in studies of the Reformation by looking into Anabaptist activities in the relatively neglected region of central Germany. As Kat Hill notes, this oversight is likely the result of the fact that Anabaptism in this context did not the fit the picture most of us hold of the movement: Anabaptists in this region tended to be thin on the ground, scattered among rural communities; they did not separate from the world and their neighbours in ways we would expect; and they produced few noteworthy writings or leaders. These characteristics, she claims, allow us to think about Anabaptism in new ways that provide an opportunity to pursue a goal long sought by scholars: a truly descriptive social history of the movement that gets beyond accounts of it based largely on more prescriptive statements derived from theological and devotional tracts, polemics and apologetics, and martyrologies. Finally, Hill presents her approach to this subject as a new method to unravel the formation of religious identity in early modern Europe more generally. 
To attain her goals, Hill offers us a “'thick description' of Anabaptism as a phenomenon understood in its cultural milieu, not a description of leaders and deviations from other confessions" (15). She constructs this thick description by approaching the topic through seemingly traditional categories, but in new and interesting ways. Chapter 1 serves as an introduction to the work as a whole. The next two chapters set up the general context in which central German Anabaptism arose, and highlight the ways in which that context influenced the development of the movement: chapter 2 focuses on the political, social, economic, and religious context, while chapter 3 concentrates more specifically on the significance of the Peasants' War for the rise of Anabaptism in the region. In the latter case the focus is on how Anabaptists remembered events and personalities from the Peasants' War in what Hill claims to be a study in the recreation of social memory. Chapters 4 and 5 turn to theology and practical piety, specifically Anabaptist understandings of the two sacraments retained by the Lutherans: Baptism and the Lord's Supper. In both cases, Hill characterizes central German Anabaptist statements on these subjects more as creative responses to Lutheran challenges to traditional thinking that failed to fill the void they created than as the simple adoption of positions taken by Anabaptist leaders elsewhere. Chapter 6, a study of statements about gender, sex, and marriage in sources relating to central German Anabaptists, tries to move beyond "anachronistic and teleological" discussions about the status of women in the movement to investigate how the Anabaptists reworked traditional rhetoric about gender to challenge prevailing hierarchies. Finally, chapter 7 uses the records of one of the last trials of an Anabaptist in Thuringia, that of Hans Thon, to measure the long-term impact of Anabaptism in the region. Here, Hill comes to the interesting conclusion that over the course of the sixteenth century the authorities' concerns about Anabaptism shifted from fears about sedition to worries about the efficacy of their confessionalization processes.

Baptism, Brotherhood, and Belief delivers on many of the promises it makes. It suggests novel and potentially valuable approaches to a number of subjects at the centre of scholarship on Anabaptism, the Reformation, and early modern religious history. However, as with many self-consciously innovative works, it can at times over-emphasize its own novelty and parody the scholarship that came before it. More importantly, like so much of the scholarship it claims to supersede, this work wrestles with the question of who was and who was not 
an Anabaptist. Hill's definition is remarkably inclusive: “[...] all those people whose lives were changed by the arrival of Anabaptist preachers. This might not mean a permanent or complete change, or even approval of Anabaptism, but to understand the impact that Anabaptist ideas had on people's lives we must appreciate its low-level, almost untraceable legacy" (11). One wonders, though, if, in getting away from a confessionally-driven history of Anabaptism as a history of the heroes of the faith, Hill has not gone too far. "Anabaptist" was not a term used by Anabaptists; it was employed by the authorities to justify an appeal to precedent in imperial law to execute religious dissenters. Hill's sources are overwhelmingly trial records, and one has to wonder if she has not exchanged a definition of Anabaptism created by the spiritual heirs of some "Anabaptists" for one created by their contemporary enemies. In the end, this very good book is more about religious dissent in central Germany, and the reaction of the authorities to it, than about "Anabaptism" in central Germany. From the perspective of the study of the Radical Reformation and the groups within it, Hill seems to lose sight of the trees for the forest.

GEOFFREY DIPPLE

University of Alberta

Hunger Parshall, Karen, Michael T. Walton, and Bruce T. Moran, eds. Bridging Traditions: Alchemy, Chemistry, and Paracelsian Practices in the Early Modern Era.

Early Modern Studies 15. Kirksville, MO: Truman State University Press, 2015. Pp. xxii + 311. 24 ill. ISBN 978-1-61248-134-0 (hardcover) US\$50.

For some years now, scholars of early modernity have understood that the oldschool notion of sixteenth- and seventeenth-century science as a steady march from darkness into light simply will not do, and that scientific endeavour in the period was both more complex and far stranger than such a linear narrative allows. One of the pioneers in building this understanding was the late Allen G. Debus, whose work on Paracelsus and early modern chemistry and medicine helped to expand the notion of "science" beyond just physics and mathematics, and to show that in order to make sense of what Paracelsus and others thought they were doing, we have to try to understand them on their own terms instead 